\title{
Urinary Continence and Sexual Functioning (Risk Factors and Prevention for Disorders of Sexual Intercourse in Persons with UI)
}

\section{Mariola Bidzan*}

Institute of Psychology, University of Gdansk, Gdansk, Poland

Researchers often state that urinary incontinence (UI) has unfavorable consequences for the sexual functioning of persons who are affected by this disorder [1]. Is this in fact the case? What decides whether the sexual life of persons with UI will deteriorate - or improve? Could it have something to do with UI during intercourse itself?

From the research available to date it can be inferred that while UI can indeed affect the sexual functioning of partners [2-4], still, $\mathrm{UI}$ is not the only factor, nor is it the only important factor, affecting the evaluation of the quality of sexual life. This has been confirmed by some of the earlier research performed by our team $[5,6]$, which indicated that UI in women can affect marital functioning, especially sexual relations, which is manifested inter alia by earlier withdrawal from sexual activity, especially in women for whom this aspect of life is of less importance, or by a change in the strategy for coping with UI during intercourse. What is most important for the evaluation of the quality of sexual relations in female UI patients, however, is other pathology that may occur in their families, especially alcoholism in the partner (which affects ca. 33\% of our patients). In our research [7], the patients mentioned causes for which they themselves were responsible (illness, reduced libido, problems related to job and career), and those for which their partners were responsible (illness, reduced libido) or both were responsible (the quality of the marital relationship or the partnership).

It is estimated that about $10-25 \%$ of women with UI have problems with incontinence during sexual intercourse $[8,9]$. Most of them make some effort to cope with the problem. The coping strategies mentioned in the literature include hiding UI from the partner and avoiding sexual activity [9-13]. Are there other ways as well of coping with urinary incontinence during sexual intercourse for female patients with stress urinary incontinence (SUI)? Can they be categorized? And which of these methods promotes better sexual functioning? Patients list many ways of coping with UI during intercourse, and it is not easy to categorize them. In my own research [7], in order to impose some order on all the various ways of coping with UI during sexual intercourse, I used the "competent judges" method. Then I divided the methods into four overlapping groups:

- adaptive for women (AW), which included urination before intercourse, intercourse only in "safe" places (e.g. one's own bedroom), limitation of vigorous physical activity during intercourse, urination after intercourse;

- adaptive for men (AM), which included, in addition to those already mentioned as adaptive for women, also more frequent faking or avoidance of orgasm due to fear of urine emission, prolongation of foreplay, and reducing the duration of penetration to the time essential for the partner's fulfillment;

- non-adaptive for women (NW), such as limiting the frequency of sexual intercourse, faking or avoiding orgasm, giving up completely on orgasm, limiting the duration of the sexual encounter to the time actually needed for the partner's fulfillment, adapting the time of intercourse to the rhythm of urinary urgency, fulfilling the partner without penetration, giving up oral sex, complete withdrawal from intercourse;

- non-adaptive for men (NM), which involves limiting the frequency of intercourse, more frequent satisfaction of the partner without penetration, giving up oral sex, complete withdrawal from intercourse.

Which strategy will be used by women with UI depends primarily on the type of UI, but also on the intensity of the symptoms. However, a lower intensity of UI symptoms does not directly correlate with the use of more adaptive strategies for coping with UI. Women with Grade 2 SUI have a worse self-evaluation in the domain of sexual functioning than do women with Grade 3 SUI. Apart from the objective degree of symptom intensity, the subjective experience also has an impact on the evaluation of sexual relations. That in turn is associated with personality traits, among which neurotism and agreeability, along with a feeling of one's own effectiveness, seem to be most responsible for the subjective reception of the symptoms and sequelae of UI.

The results from our research to date indicate that the choice of strategies for coping with UI depends on whether or not UI during intercourse was the only reason for limiting sexual expression. Women with UI mention a number of other reasons for deteriorating sexual functioning, including poor bonding with the partner, deterioration of the quality of sex on the partner's side, the partner's alcoholism, physical violence, rape, diminished libido in the partner, chronic illness of the woman or her partner, financial problems, difficulties with living quarters, vocational or career problems, fear of unplanned pregnancy [5].

On the other hand, it is estimated that at least $14 \%$ of women and $15 \%$ of men who do not have UI are dissatisfied with their sexual life. An analysis of the results of 22 research projects involving the general population has revealed the widespread occurrence of sexual problems, especially disturbances of sexual desire (which affects $15 \%$ of men and $35 \%$ of women) and problems with orgasm (5\% of men and $30 \%$ of women $[2,14]$ ) It should be pointed out, however, that this same research found $97 \%$ of men and $77 \%$ of women to be

${ }^{*}$ Corresponding author: Mariola Bidzan, Institute of Psychology, University of Gdansk, Gdansk, Poland, Tel: +48-602-31-61-61; E-mail: mabi4@wp.pl

Received December 29, 2011; Accepted December 30, 2011; Published January 03, 2012

Citation: Bidzan M (2011) Urinary Continence and Sexual Functioning (Risk Factors and Prevention for Disorders of Sexual Intercourse in Persons with UI). $J$ Socialomics 1:e105. doi:10.4172/2167-0358.1000e105

Copyright: @ 2011 Bidzan M. This is an open-access article distributed under the terms of the Creative Commons Attribution License, which permits unrestricted use, distribution, and reproduction in any medium, provided the original author and source are credited. 
Citation: Bidzan M (2011) Urinary Continence and Sexual Functioning (Risk Factors and Prevention for Disorders of Sexual Intercourse in Persons with UI). J Socialomics 1:e105. doi:10.4172/2167-0358.1000e105

Page 2 of 2

satisfied with their sexual life. In Polish research conducted by LewStarowicz [9] on a group of 406 women, some $25 \%$ of the subjects were experiencing reduced or absent sexual needs, while $27 \%$ reported problems with orgasm (10\% had no orgasms at all, while $17 \%$ had difficulty in achieving it). There has also been research, such as the work done by Wellings[16], which, based on results taken from very large populations (from 10,000 to 50,000 persons), clearly indicates that the relation between the perception of one's own physical health and sexual behavior is very slight.

At present it is impossible to state unequivocally that UI is the only or the primary cause for changes and limitations in sexual relations. It would appear that other disorders may have a greater impact, such as alcohol dependency, as well as material problems with housing, jobs, or money. Given that sexual expression is a vital part of interpersonal relations, and has an effect on physical, mental, and social wellbeing, and can thus improve the quality of life, this issue requires further research.

\section{References}

1. Shaw Ch (2002) A systematic review of the literature the prevalence of sexual impairement in women with urinary incontinence and the prevalence of urinary leakage during sexual activity. European Urology 42: 432-440.

2. Nathan S (1986) The epidemiology of the DSM-III psychosexual dysfunctions, Journal of Sex and Marital Therapy 4: 267-281.

3. Salonia A, Briganti A, Deho F, Zanni G, Rigatti P, et al. (2006) Women's sexual dysfunction : a review of the "surgical landscape" European Urology 1: 44-52.

4. Lew Starowicz Z (2006) Seksualność a jakość życia człowieka. Przegląd Seksuologiczny 5: 21-26.

5. Smutek J, Grzybowska M, Bidzan M, Płoszyński A (2004a) Nietrzymanie moczu u kobiet. Strategie radzenia sobie $z$ problemem gubienia moczu w czasie współżycia, Annales Universitas Mariae Curie -Skłodowska. Sectio D 14: 180-186.

6. Smutek J, Bidzan M, Grzybowska M, Płoszyński A (2004b) Wpływ stosowanych przez kobiety strategii radzenia sobie z problemem gubienia moczu w czasie współżycia na seksualne funkcjonowanie ich partnerów, Annales Universitas Mariae Curie -Skłodowska. Sectio D 14: 187-193.

7. Bidzan M (2008) Jakość życia pacjentek z róźnym stopniem nasilenia wysiłkowego nietrzymania moczu, Oficyna Wydawnicza Impuls, Kraków 26.90-28.30.

8. Gordon R, Groutz A, Sinai T, Wiezman A, Lessing JB, et al. (1999) Sexual Dysfunction in women attending an urogynecology clinic. Int Urogynecol J 10: 325-328.

9. Krauze Balwińska Z, Fryczkowski M, Paradysz A, Bujak Rosenbeiger E (2001) Problemy diagnostyczne oraz jakość życia pacjentek z wysiłkowym nietrzymaniem moczu. Problemy Medycyny Rodzinnej 2: 31-36.

10. Lew Starowicz Z (2000) Zaburzenia seksualne u kobiet $z$ problemam urologicznymi. Nowa Medycyna 101: 35-37.

11. Lamm D, Fischer W, Maspfuhl B (1986) Sexuality and urinary incontinence. Zentralblatt für Gynäkologie 108: 1425-1430.

12. Brown JS, Subak LL, Gras J, Brown BA, Kuppermann M, et al. (1998) Urge incontinence: the patient's perspective. Journal of Women's Health 7: 12631269 .

13. Bodden Heidrich R, Beckmann MW, Libera B, Rechenberger I, Bender HG (1999) Psychosomatic aspects of urinary incontinence. Arch Gynecol Obstet 262: 151-158.

14. Baldwin D, Thomas S (2000) Depresja a zaburzenia seksualne, Gdańsk: Via Medica.

15. Lew Starowicz Z (2002) Zdrowie seksualne Polaków 2002. Medycyna po Dyplomie 11: 16-21.

16. Wellings K, Field J, Johnson AM, Wadsworth J, Bradshaw S (1994) Sexua Behaviour in Britain. The national survey of sexual attitudes and lifestyles. London: Penguin. 